Arkivoc

Free to Authors and Readers
A Platinum Open Access Journal for Organic Chemistry
Paper

Arkivoc 2021, part x, 54-63

\title{
An efficient method for the synthesis of 6,7-bis(alkylthio- or alkylamino- substituted)quinoline-5,8-diones via nucleophilic addition/oxidation of alkylthio and alkylamino derivatives to quinoline-5,8-dione
}

\author{
Herman H. Odens, ${ }^{\text {*a }}$ Trevor S. Silva, ${ }^{\mathrm{b}}$ Candace N. Olusola, ${ }^{\mathrm{b}}$ Herman H. Odens Jr., ${ }^{\mathrm{b}}$ Victoria A. Howe, ${ }^{\mathrm{b}}$ and \\ Anna I. Wijatyk ${ }^{b}$
}

aUniversity of Tennessee at Chattanooga, Department of Chemistry and Physics, Grote Hall 223, 615 McCallie Ave., Chattanooga, TN 37403, USA

${ }^{b}$ Southern Adventist University, Chemistry Department, Hickman Science Center, PO Box 370, Collegedale, TN 37315, USA

Email: herman-h-odens@utc.edu

Dedicated to all my present and past students

Received 11-24-2020

Accepted 09-29-2021

Published on line $10-17-2021$

\section{Abstract}

A new variety of 6,7-bis(alkylthio- or alkylamino-substituted)quinoline-5,8-diones were prepared by the addition of mercaptans or amino nucleophiles to quinoline-5,8-dione after subsequent oxidation with $\mathrm{NaIO}_{4}$. The core quinoline-5,8-dione intermediate was prepared from the oxidation of 5-quinolinol or 8-quinolinol by [bis(trifluoroacetoxy)iodo]benzene, PIFA, in the presence of water and acetonitrile as solvents. No good leaving groups were utilized to insert the alkylthio or alkylamino groups into the quinoline ring. The synthesized compounds will be tested for their anti-inflammatory, anti-bacterial and tuberculostatic inhibition activities at a later stage.<smiles>[R]C1=C([Z])C(=O)c2ncccc2C1=O</smiles>

Keywords: 6,7-Bis(alkylthio-substituted)quinoline-5,8-diones, 6,7-bis(alkylamino-substituted)quinoline-5,8diones, quinolinequinones, oxidation with $\mathrm{NalO}_{4}$, addition/oxidation method, heterocycles. 


\section{Introduction}

Quinolinequinones have shown promise in possible anti-tumor, ${ }^{1-4}$ anti-cancer, ${ }^{5}$ anti-bacterial, ${ }^{6}$ trypanocidal, ${ }^{7}$ anti-tuberculosis, ${ }^{8}$ anti-inflammatory, ${ }^{9}$ anti-malarial agents, ${ }^{10}$ and anti-fungal. ${ }^{11}$<smiles>[X]c1ccc([Y])c2ncccc12</smiles>

1a where $X=\mathrm{OH}, Y=\mathrm{H}$ 1b where $X=\mathrm{H}, Y=\mathrm{OH}$<smiles>O=C1C=CC(=O)c2ncccc21</smiles>

2
1) $H Z-R^{1}$

2) $\mathrm{NaIO}_{4}$ where $\mathrm{Z}=\mathrm{S}$, or $\mathrm{NR}^{2}$<smiles>[R]C1=C([Z])C(=O)c2ncccc2C1=O</smiles>

3a-m

where $\mathrm{R}^{1}=$ alkyl, aryl and $\mathrm{R}^{2}=\mathrm{H}$, alkyl

Scheme 1. General scheme for the synthesis of 6,7-bis(alkylthio- or alkylamino-substituted)quinoline-5,8diones.

Studies have shown quinolinequinones as more superior substrates than analogous indolequinones for recombinant human $\mathrm{NAD}(\mathrm{P}) \mathrm{H}$ :quinone oxidoreductase ( $\mathrm{NQO1}$ ) as bioreductive antitumor drugs. ${ }^{12}$ Mulchin et al. synthesized a range of 5,8-quinolinequinones to study their anti-inflammatory and anti-tumor properties to ultimately advance in building a larger, more effective bank of therapeutic quinolinequinones. The replacement of substituents displaying electron-withdrawing properties at the 6- and/or 7-positions of the compounds has increased their speed in breaking down DNA, which is a key anti-tumor characteristic. ${ }^{13}$ Amines and thiols have been the primary type of precursors for the substituents attached to the 5,8quinolinequinones with the nitrogens and sulfurs, respectively, providing the source of attachment between the compounds and their alkyl groups. ${ }^{13}$ Davioud-Charvet et al. prepared and tested various aza-analoges of 1,4-naphthoquinones and menadione as inhibitors and substrates of the plasmodial thioredoxin and glutathione reductases as well as the human glutathione reductase. ${ }^{14}$ Most of the syntheses to produce substituted-quinoline-5,8-diones involves the use of good leaving groups for the nucleophilic displacement of those groups. Here, we would like to present a way to design and generate a new class of 6,7-bis(alkylthio- or alkylamino-substituted)-quinoline-5,8-diones via an efficient addition/oxidation method without the need of leaving groups (Scheme 1). This work presents a new and more efficient synthetic methodology of an important class of organic molecules. Herein, our research group would like to show the synthetic application on how our 6,7-bis(alkylthio- or alkylamino-substituted)quinoline-5,8-dione derivatives were designed and synthesized in our laboratory. 


\section{Route 1. Sulfur Nucleophiles}<smiles>[R1]SC1=CC(=O)c2ncccc2C1=O</smiles>

\section{Route 2. Nitrogen Nucleophiles}<smiles>[X]c1ccc([X])c2ncccc12</smiles>

1a,b

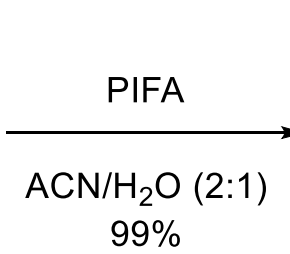

$99 \%$

1a where $X=\mathrm{OH}, Y=\mathrm{H}$

1b where $X=H, \quad Y=O H$<smiles>O=C1C=CC(=O)c2ncccc21</smiles>

2<smiles>[R]N([R])C1=C(N([R])[R])C(=O)c2ncccc2C1=O</smiles>

3k
3I, 3m

$$
\text { where } \mathrm{R}^{1}=\text { alkyl, aryl } \quad \text { where } \mathrm{R}^{2}=\mathrm{H} \text {, alkyl }
$$

Scheme 2. Synthetic routes employed for the target compounds.

\section{Results and Discussion}

Quinoline-5,8-dione intermediate 2 was synthesized and used without further purification from the oxidation of 5- or 8-quinolinol $\mathbf{1 a , b}$ with [bis(trifluoroacetoxy)iodo]benzene, PIFA. ${ }^{14}$ A new variety of 6,7-bis(alkylthiosubstituted)quinoline-5,8-diones 3a-m was prepared by the addition of alkylthiols to quinoline-5,8-dione after subsequent oxidation with $\mathrm{NaIO}_{4}$ (Table 1). No good leaving groups were utilized to insert the alkylthio groups into these heterocyclic rings. Our research group envisioned having two groups of nucleophiles added. One group consisted of sulfur nucleophiles and another of nitrogen nucleophiles (Scheme 2). Due to the neighboring electron donation of the nitrogen atom in quinoline-5,8-dione $\mathbf{2}$ to the quinoid ring, it was expected that the nucleophilic addition would favor the C- 6 position. The fact that we were able to isolate five examples of mono-alkythiolation and mono-aminoalkylation products indicates that our prediction was correct. Mono-alkythiolation and mono-aminoalkylation was observed as the only compound when nucleophiles were bulky enough to block a second addition on the C-7 carbon of the benzoquinoid ring, or if the mono-thio or mono-aminoalkylated substrate would have a locked conformation with the carbonyl at the 8position. For compound $\mathbf{3 j}$, mono-alkythiolation was the major product possibly due to hydrogen bonding stabilizing the conformation for a secondary nucleophilic addition and for compounds $\mathbf{3 h}, \mathbf{3 i}, \mathbf{3 l}$, and $\mathbf{3 m}$, steric factors were the cause (Figure 1). On the other hand, when the nucleophile was less sterically hindered, bisalkythiolation and bis-aminoalkylation was preferred as was the case for compounds $\mathbf{3 a - g}$ and $\mathbf{3 k}$ in which the second nucleophile would attach to the benzoquinoid ring via a Michael-addition without the help of the electronic effects of the nitrogen atom activating the adjacent ring. 
Table 1. Synthetic results. Compounds $\mathbf{3 a - g}$ and $\mathbf{3} \mathbf{j}-\mathbf{m}$ were synthesized using Method A and compounds $\mathbf{3 h}$ and $3 \mathbf{i}$ were synthesized via Method B. Shown are the isolated yields of each product
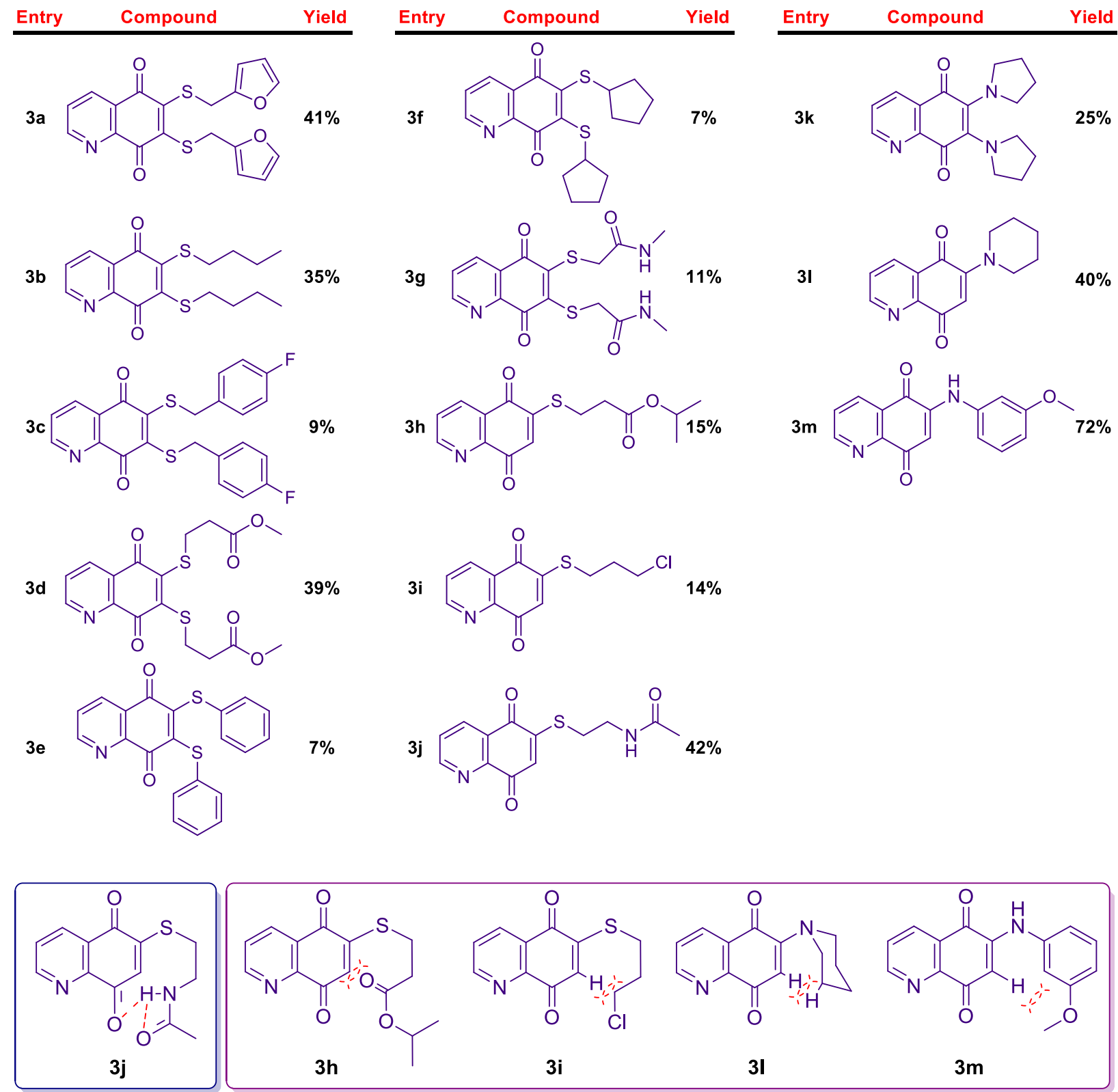

Figure 1. Hydrogen bonding in $\mathbf{3} \mathbf{j}$, and steric factors in $\mathbf{3 h}, \mathbf{3 i}, \mathbf{3 l}$ and $\mathbf{3 m}$ contributed to the formation of only mono-alkythiolated and mono-aminoalkylated compounds for these syntheses.

An attempt to propose a reaction mechanism for the synthesis of 6,7-bis(alkylthio- or alkylaminosubstituted)quinoline-5,8-diones is depicted on Scheme 3. The mechanism shown reflects the monoalkythiolation and mono-aminoalkylation process. For the bis-alkythiolated and bis-aminoalkylated compounds, the mono-alkylthiolated and mono-aminoalkylated compound undergoes 1,4-nucleophilic addition to $\mathrm{C}-7$, followed by oxidation with $\mathrm{NaIO}_{4}$ to reform the carbonyl group back to complete the reactions sequence. An interesting aspect of this chemistry is that the reaction is biphasic and methanol is used as a carrier or phase transfer catalyst between the organic and the aqueous layer, transferring any desired compound into the organic phase. 


\section{Proposed Mechanism}
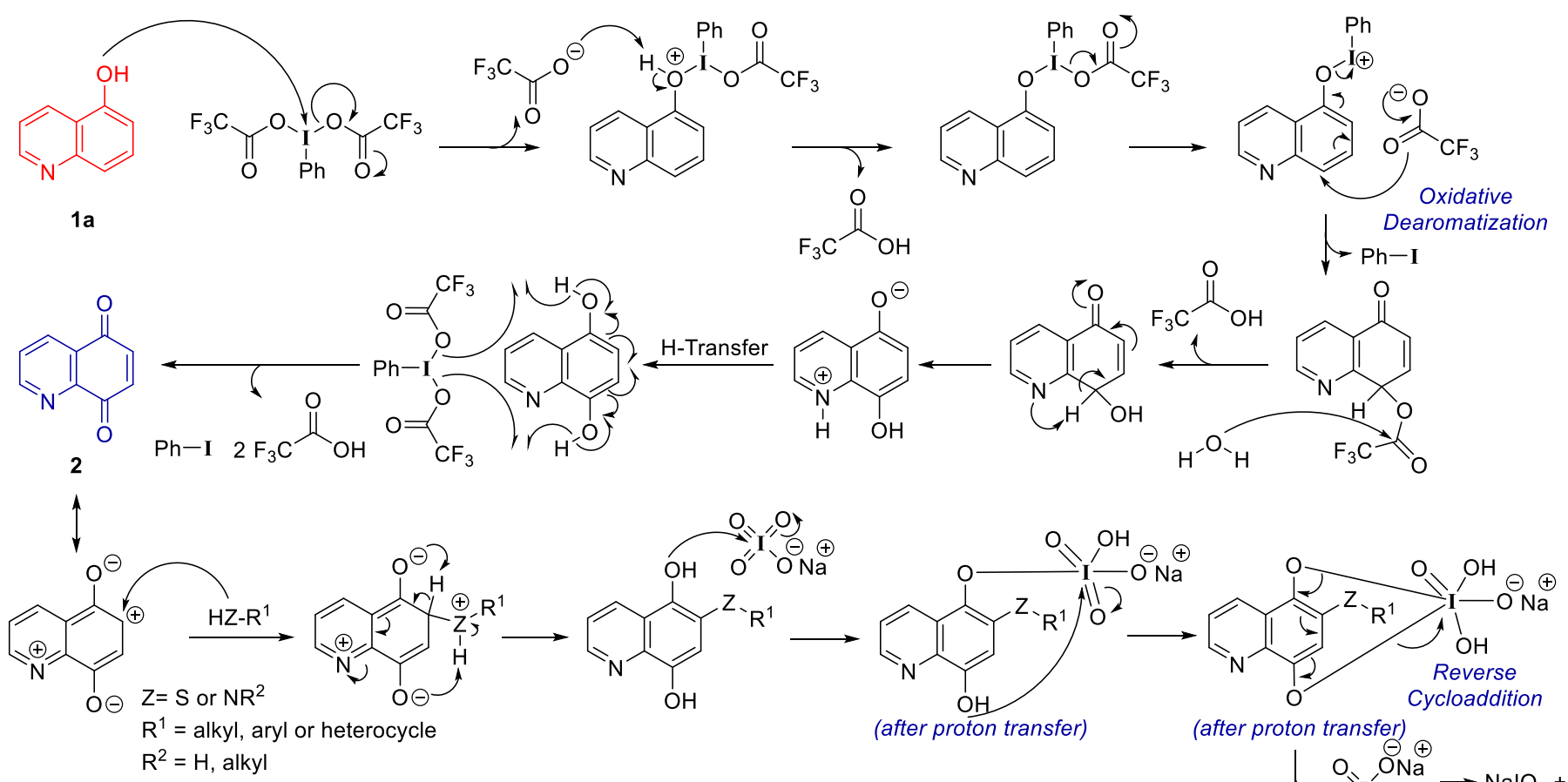
(after proton transfer)
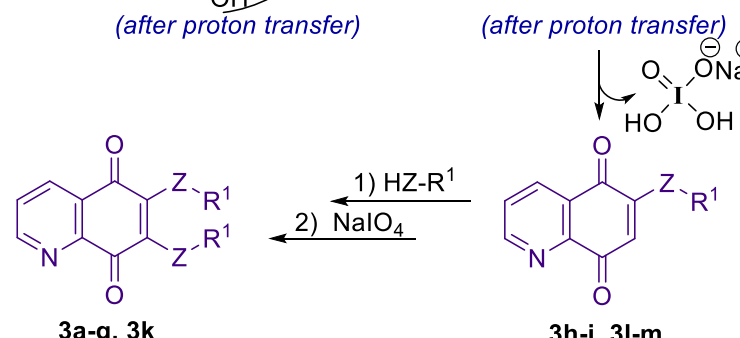

2) $\frac{\text { 1) } \mathrm{HZ}_{\mathrm{NaIO}}}{4}$

3a-g, 3k

3h-j, 3I-m

Scheme 3. A proposed mechanism for the synthesis of 6,7-bis(alkylthio- or alkylamino-substituted)quinoline5,8-diones 3a-m.

\section{Conclusions}

The success of the experiments is seen by the ability of the novelty synthesis to produce 6-(alkylthio- and alkylamino)- and bis-6,7-(alkylthio- and alkylamino)-substituted-5,8-quinolinequinones. This oxidation/addition synthesis is more efficient than the currently used methods which employ leaving groups. This innovative synthesis involves only three steps. Thirteen examples of these novel compounds have been synthesized. Since we were focusing on the medicinal chemistry portion of the project, our main goal was to generate a library of compounds for further biological testing. Once a library of compounds has been collected, the compounds made would later be tested on their anti-inflammatory, turberculostatic, and antibacterial activities.

\section{Experimental Section}

General. All materials and reagents were commercially available and purchased from: Acros, TCl America, Aldrich, Fischer, and VWR. The equipment used included: CG-1991-P Pie Blocks, the reaction blocks and the 
safety holders, CG-1994 Chemglass Optimag magnetic hot plat stirrers with safety controls, $22 \mathrm{~mL}$ vials, micromagnetic stirrers, a RE11 Buchi Rotavapor 1024648, two Wilmad Lab Glass Rotavapor WG-EV311, AnalTech Silica Gel G $500 \mu \mathrm{m}$ 20x20 cm Prep-scored, AnalTech Silica Gel GHLF $250 \mu \mathrm{m}$ 10x20 cm scored, a short wave UV lamp, $254 \mathrm{~nm}$, and standard laboratory glassware. Nuclear magnetic resonance spectra were carried out at the University of Tennessee at Chattanooga (UTC) using a Jeol $400 \mathrm{MHz}$ NMR. Chemical shifts $(\delta)$ in ${ }^{1} \mathrm{H} N M R$ spectra are expressed in ppm downfield of tetramethylsilane and were referenced to the residual solvent peak. Analytical LCMS was performed on an Agilent 1000 Series LC and an Agilent G1946D MS tandem or an Acquity Ultra Performance Liquid Chromatography instrument coupled with a Micromass Quattro Micro API ESCi Mass Spectrometer at UTC.

\section{Synthesis of Quinoline-5,8-dione (2). ${ }^{14}$}

A sample of 8-quinolinol (1b, $0.145 \mathrm{~g}, 1.00 \mathrm{mmol}$ ) was treated with bis(trifluoroacetoxy)iodobenzene (PIFA, $0.946 \mathrm{~g}, 2.2 \mathrm{mmol})$. The 8-quinolinol was dissolved in a 2:1 ratio mixture of acetonitrile and water ( $3 \mathrm{~mL}$ total) and mixed with the PIFA, dissolved in an identical mixture. The 8-quinolinol was cooled to $0^{\circ} \mathrm{C}$ before being added dropwise to the PIFA in the reaction vessel (the mixture became a dark orange color). The reaction was carried out for 30 minutes at $0^{\circ} \mathrm{C}$ and then at room temperature for one hour under constant stirring. The extent of the reaction was monitored by thin layer chromatography (TLC, $250 \mu \mathrm{m}$ ). The desired quinoline-5,8dione intermediate was formed and the acetonitrile solvent was evaporated under reduced pressure. The intermediate was dissolved in approximately $10 \mathrm{~mL}$ of water and extracted using five, $20 \mathrm{~mL}$ portions of dichloromethane (DCM). The orange-colored organic portions were collected and dried with anhydrous sodium sulfate $\left(\mathrm{Na}_{2} \mathrm{SO}_{4}\right)$. The mixture was filtered and washed with DCM and the yellow filtrate was collected. TLC was run to confirm the presence of the intermediate and the DCM solvent was evaporated under reduced pressure to produce compound 2 ( $0.157 \mathrm{~g}$, 99\% crude yield). The remaining crude sample had a dark orange color and was used immediately after without further purification.

General Method and Procedure for the Synthesis 6-(alkylthio- and alkylamino)- and bis-6,7-(alkylthio- and alkylamino)-substituted-5,8-quinolinequinones (Compounds $\mathbf{3}$ a-g and $\mathbf{3 j - m}$ ).

Method A (step-wise):

The quinoline-5,8-dione $(2,0.050 \mathrm{~g}, 0.31 \mathrm{mmol})$ intermediate was dissolved in approximated $2 \mathrm{~mL}$ of methanol and treated with either a alkylthiol or alkylamino nucleophile in a 1:1 mmol ratio. The reaction was stirred at room temperature for one day, monitored through TLC, and stopped by evaporating the methanol under reduced presure. The resulting quinolinequinols intermediates were dark brown in color and weighed to determine the subsequent reaction molar quantities and used without further purification onto the next step.

The quinolinequinols (reduced forms of $\mathbf{3} \mathbf{~ a - g}$ and $\mathbf{3} \mathbf{j}-\mathbf{m}$ ) were oxidized using sodium periodate in a 1:1 $\mathrm{mmol}$ ratio. The crude mixtures were dissolved in DCM and methanol, in a 5:4 ratio, and the sodium periodate was dissolved in water. The milliliters of water were matched to the mmol quantity of the secondary intermediates used and the 1.25:1 DCM to methanol ratio used the portion of water as the baseline volume. The crude mixtures and reagents were mixed and the reactions ran for twenty minutes at room temperature while being stirred. The reactions were monitored through TLC using hexane:ethyl acetate (7:3) or (1:1) depending on the retention factor assigned, the organic layers (dark brown-colored) were collected using DCM and the reactions were stopped by drying over anhydrous sodium sulfate. The mother liquid containing the target compounds was decanted and the DCM/methanol solvent was evaporated under reduced pressure. The resulting dark brown solid samples were purified by the preparative TLC purification method.

General Method and Procedure for the Synthesis of 6-(alkylthio)quinoline-5,8-diones (3h, and 3i). Method B (one-pot): 
Quinolinequinone $(2,0.838 \mathrm{mmol})$, previously made by the oxidation of quinolin-5-ol (1a) with phenyliodine bis(trifluoroacetate) (PIFA) ${ }^{14}$ was dissolved in $4.19 \mathrm{ml}$ of dichloromethane (DCM), and $840 \mu \mathrm{L}$ of methanol. The reaction mixture was treated with $0.227 \mathrm{mmol}$ of thiol derivative added drop-wise follow by treatment with a solution of $0.454 \mathrm{mmol}$ of sodium periodate dissolved in $1.77 \mathrm{~mL}$ of water at room temperature. The mixture was stirred for 24 hours and then monitored by thin-layer chromatography (TLC) using a solvent system consisting of 1:1 hexanes and ethyl acetate. The TLC plate was placed inside of a chromatography chamber containing $10 \mathrm{ml}$ of the solvent system for 10 minutes, and it was then observed under the ultra-violet light to detect any spots that would indicate the presence of a new compound. The mixture was then filtered through Celite, which was pressed into a vacuumed fritted glass funnel. After adding $455 \mu \mathrm{L}$ of water to the filtrate, the organic layer was worked up and washed three times with $5 \mathrm{ml}$ of DCM and ultimately extracted from the aqueous layer using a separatory funnel. The organic layer was dried with sodium sulfate, and this drying agent was paper filtered out through a Buchner funnel. The solvent from the filtrate solution was removed under reduced pressure using a rotary evaporator. Final compound (3h or $\mathbf{3 i}$ ) was then purified using the preparative TLC purification method.

\section{Purification Process}

After the solvent was removed, the dried product was dissolved with minute amounts of DCM and 2-5 drops of methanol. With $35 \mathrm{ml}$ of the same solvent system used for TLC, a large-scale preparative TLC (500 $\mu \mathrm{m} 20 \mathrm{x}$ $20 \mathrm{~cm}$ ) was run for purification by dotting the entire dissolved crude product onto two opposite sides of the plate. The prep TLC plate was placed in a TLC chamber for 16 minutes for each spotted side and eluted with 35 $\mathrm{ml}$ of 1:1 ratio of hexanes and ethyl acetate.

The pure product was scraped off and poured into a $5 \mathrm{ml}$ plastic syringe with frits on both ends of the product. Then, the product was flushed with $5 \mathrm{ml}$ of 9:1 (DCM:methanol), collecting the desired product into a vial. Solvent was again removed under reduced pressure. The solvents were chased by adding $3 \mathrm{ml}$ of DCM to the dried product, and then the solvent was removed for the last time. The resulting product (3a-m) was confirmed of its chemical structure through ${ }^{1} \mathrm{H}$ NMR and LCMS.

6,7-Bis((furan-2-ylmethyl)thio)quinoline-5,8-dione (3a): Red oily film (0.125 g, 41\% yield). ${ }^{1} \mathrm{H} \mathrm{NMR}(400 \mathrm{MHz}$, DMSO- $\left.d_{6}\right) \delta 8.98(\mathrm{~s}, 1 \mathrm{H}), 8.34(\mathrm{~d}, J=7.9 \mathrm{~Hz}, 1 \mathrm{H}), 7.82(\mathrm{dd}, J=8.0,4.7 \mathrm{~Hz}, 1 \mathrm{H}), 7.51(\mathrm{~s}, 2 \mathrm{H}), 6.31(\mathrm{~s}, 2 \mathrm{H}), 6.17(\mathrm{~s}$, $2 \mathrm{H}), 4.54(\mathrm{~d}, J=8.8 \mathrm{~Hz}, 4 \mathrm{H})$. MS (ESI): $\mathrm{m} / z$ 383, found $384\left(\mathrm{C}_{19} \mathrm{H}_{13} \mathrm{NO}_{4} \mathrm{~S}_{2}[\mathrm{M}+\mathrm{H}]^{+}\right)$.

6,7-Bis(butylthio)quinoline-5,8-dione (3b): Red oily film (0.125 g, 35\% yield). ${ }^{1} \mathrm{H}$ NMR (400 MHz, DMSO- $\left.d_{6}\right) \delta$ 8.95 (ddd, $J=4.7,1.7,0.7 \mathrm{~Hz}, 1 \mathrm{H}$ ), 8.32 (ddd, $J=7.9,1.7,0.7 \mathrm{~Hz}, 1 \mathrm{H}$ ), 7.80 (ddd, $J=7.9,4.7,0.7 \mathrm{~Hz}, 1 \mathrm{H}$ ), 3.23 $(\mathrm{td}, J=7.3,5.2 \mathrm{~Hz}, 4 \mathrm{H}), 1.59-1.48(\mathrm{~m}, 4 \mathrm{H}), 1.45-1.32(\mathrm{~m}, 4 \mathrm{H}), 0.86(\mathrm{tt}, J=7.3,0.9 \mathrm{~Hz}, 6 \mathrm{H}) . \mathrm{MS}(\mathrm{ESI}): \mathrm{m} / z 335$, found $336\left(\mathrm{C}_{17} \mathrm{H}_{21} \mathrm{NO}_{2} \mathrm{~S}_{2}[\mathrm{M}+\mathrm{H}]^{+}\right)$.

6,7-Bis((4-fluorobenzyl)thio)quinoline-5,8-dione (3c): Orange dry film (0.018 g, 9\% yield). ${ }^{1} \mathrm{H} \mathrm{NMR}(400 \mathrm{MHz}$, DMSO- $\left.d_{6}\right) \delta 8.96(\mathrm{t}, J=2.4 \mathrm{~Hz}, 1 \mathrm{H}), 8.35-8.27(\mathrm{~m}, 1 \mathrm{H}), 7.85-7.76(\mathrm{~m}, 1 \mathrm{H}), 7.34-7.25(\mathrm{~m}, 4 \mathrm{H}), 7.09(\mathrm{tq}, J=$ $7.4,2.5 \mathrm{~Hz}, 4 \mathrm{H}), 4.46(\mathrm{dd}, J=10.2,2.6 \mathrm{~Hz}, 4 \mathrm{H})$. MS (ESI): $\mathrm{m} / \mathrm{z} 439.5$, found $440.5\left(\mathrm{C}_{23} \mathrm{H}_{15} \mathrm{~F}_{2} \mathrm{NO}_{2} \mathrm{~S}_{2}[\mathrm{M}+\mathrm{H}]^{+}\right)$.

Dimethyl 3,3'-((5,8-dioxo-5,8-dihydroquinoline-6,7-diyl)bis(sulfanediyl))dipropanoate (3d): Orange oily film (0.066 g, 39\% yield). ${ }^{1} \mathrm{H}$ NMR (400 MHz, DMSO- $\left.d_{6}\right) \delta 9.00(\mathrm{dd}, J=4.7,1.7 \mathrm{~Hz}, 1 \mathrm{H}), 8.38(\mathrm{dd}, J=7.9,1.7 \mathrm{~Hz}, 1 \mathrm{H})$, 7.84 (ddd, $J=7.9,4.7,1.0 \mathrm{~Hz}, 1 \mathrm{H}$ ), 3.61 (dd, $J=2.2,0.9 \mathrm{~Hz}, 6 \mathrm{H}), 3.41(\mathrm{q}, J=6.9 \mathrm{~Hz}, 4 \mathrm{H}), 2.76(\mathrm{td}, J=6.9,3.2 \mathrm{~Hz}$, $4 \mathrm{H})$. MS (ESI): $m / z$ 395.5, found $396.5\left(\mathrm{C}_{17} \mathrm{H}_{17} \mathrm{NO}_{6} \mathrm{~S}_{2}[\mathrm{M}+\mathrm{H}]^{+}\right)$.

6,7-Bis(phenylthio)quinoline-5,8-dione (3e): Orange dry film, (0.015 g, 7\% yield). ${ }^{1} \mathrm{H} \mathrm{NMR}\left(400 \mathrm{MHz}, \mathrm{DMSO}-d_{6}\right)$ $\delta 8.96(\mathrm{dd}, J=4.7,1.7 \mathrm{~Hz}, 1 \mathrm{H}$ ), 8.28 (dd, $J=7.9,1.8 \mathrm{~Hz}, 1 \mathrm{H}), 7.80$ (dd, $J=7.9,4.7 \mathrm{~Hz}, 1 \mathrm{H}$ ), 7.44 (ddd, J = 8.1, 4.9, $1.5 \mathrm{~Hz}, 4 \mathrm{H}$ ), 7.32 (dddd, $J=9.5,6.7,3.7,1.6 \mathrm{~Hz}, 6 \mathrm{H}$ ). MS (ESI): $m / z 375$, found $376\left(\mathrm{C}_{21} \mathrm{H}_{13} \mathrm{NO}_{2} \mathrm{~S}_{2}[\mathrm{M}+\mathrm{H}]^{+}\right)$.

6,7-Bis(cyclopentylthio)quinoline-5,8-dione (3f): Orange dry film, $\left(0.060 \mathrm{~g}, 7 \%\right.$ yield). ${ }^{1} \mathrm{H} \mathrm{NMR}(400 \mathrm{MHz}$, DMSO- $\left.d_{6}\right) \delta 8.97(\mathrm{dd}, J=4.7,1.7 \mathrm{~Hz}, 1 \mathrm{H}), 8.34(\mathrm{dd}, J=7.9,1.7 \mathrm{~Hz}, 1 \mathrm{H}), 7.81(\mathrm{dd}, J=7.8,4.7 \mathrm{~Hz}, 1 \mathrm{H}), 4.28(\mathrm{dtt}, J$ 
$=12.4,7.1,5.3 \mathrm{~Hz}, 2 \mathrm{H}), 1.99-1.93(\mathrm{~m}, 4 \mathrm{H}), 1.73-1.64(\mathrm{~m}, 4 \mathrm{H}), 1.60-1.51(\mathrm{~m}, 8 \mathrm{H}) . \mathrm{MS}(\mathrm{ESI}): \mathrm{m} / \mathrm{z} 359$, found $360\left(\mathrm{C}_{19} \mathrm{H}_{21} \mathrm{NO}_{2} \mathrm{~S}_{2}[\mathrm{M}+\mathrm{H}]^{+}\right)$.

2,2'-((5,8-Dioxo-5,8-dihydroquinoline-6,7-diyl)bis(sulfanediyl))bis( $N$-methylacetamide) (3g): Brown dry film, (0.0095 g, 11\% yield). ${ }^{1} \mathrm{H}$ NMR $\left(400 \mathrm{MHz}, \mathrm{DMSO}-d_{6}\right) \delta 8.98(\mathrm{dd}, J=4.7,1.7 \mathrm{~Hz}, 1 \mathrm{H}), 8.33(\mathrm{dd}, J=7.9,1.7 \mathrm{~Hz}$, $1 \mathrm{H}), 7.82(\mathrm{dd}, J=7.9,4.7 \mathrm{~Hz}, 1 \mathrm{H}), 4.13(\mathrm{~s}, 2 \mathrm{H}), 4.11(\mathrm{~s}, 2 \mathrm{H}), 3.63(\mathrm{~d}, J=1.6 \mathrm{~Hz}, 6 \mathrm{H})$. MS (ESI): $m / z 365.5$, found $366.5\left(\mathrm{C}_{15} \mathrm{H}_{15} \mathrm{~N}_{3} \mathrm{O}_{4} \mathrm{~S}_{2}[\mathrm{M}+\mathrm{H}]^{+}\right)$.

Isopropyl 3-((5,8-dioxo-5,8-dihydroquinolin-6-yl)thio)propanoate (3h): Yellow oily film, (0.0378 g, 15\% yield). ${ }^{1} \mathrm{H}$ NMR $\left(400 \mathrm{MHz}, \mathrm{DMSO}-d_{6}\right) \delta 8.99$ (dd, $\left.J=4.6,1.7 \mathrm{~Hz}, 1 \mathrm{H}\right), 8.35$ (dd, $J=7.9,1.7 \mathrm{~Hz}, 1 \mathrm{H}$ ), 7.85 (dd, $J=7.9,4.7$ $\mathrm{Hz}, 1 \mathrm{H}), 4.91(\mathrm{dq}, J=11.5,6.3 \mathrm{~Hz}, 1 \mathrm{H}), 3.19(\mathrm{t}, J=6.8 \mathrm{~Hz}, 1 \mathrm{H}), 2.90(\mathrm{t}, J=6.9 \mathrm{~Hz}, 1 \mathrm{H}), 2.73(\mathrm{t}, J=6.8 \mathrm{~Hz}, 1 \mathrm{H})$, $2.66(\mathrm{t}, J=6.9 \mathrm{~Hz}, 1 \mathrm{H}), 1.20(\mathrm{dd}, J=6.7,6.2 \mathrm{~Hz}, 6 \mathrm{H}) . \mathrm{MS}(\mathrm{ESI}): \mathrm{m} / z 305$, found $306\left(\mathrm{C}_{15} \mathrm{H}_{15} \mathrm{NO}_{4} \mathrm{~S}[\mathrm{M}+\mathrm{H}]^{+}\right)$and 328 $\left([\mathrm{M}+\mathrm{Na}]^{+}\right)$.

6-((3-Chloropropyl)thio)quinoline-5,8-dione (3i): Light brown dry film, $\left(0.0279 \mathrm{~g}, 14 \%\right.$ yield). ${ }^{1} \mathrm{H}$ NMR (400 $\left.\mathrm{MHz}, \mathrm{DMSO}-d_{6}\right) \delta 8.99(\mathrm{dd}, J=4.7,1.7 \mathrm{~Hz}, 1 \mathrm{H}), 8.35$ (dd, $\left.J=7.9,1.7 \mathrm{~Hz}, 1 \mathrm{H}\right), 7.86(\mathrm{dd}, J=7.9,4.7 \mathrm{~Hz}, 1 \mathrm{H}), 6.88$ $(\mathrm{s}, 1 \mathrm{H}), 3.78(\mathrm{~d}, J=6.4 \mathrm{~Hz}, 1 \mathrm{H}), 3.72(\mathrm{t}, J=6.3 \mathrm{~Hz}, 1 \mathrm{H}), 3.09(\mathrm{~d}, J=7.3 \mathrm{~Hz}, 1 \mathrm{H}), 2.85-2.80(\mathrm{~m}, 1 \mathrm{H}), 2.18-2.08$ (m, 2H). MS (ESI): $\mathrm{m} / z{ }^{35} \mathrm{Cl}: 267$ and ${ }^{37} \mathrm{Cl}: 269$, found $\left.268\left(\mathrm{C}_{12} \mathrm{H}_{10} \mathrm{ClNO}{ }_{2} \mathrm{~S}\left[{ }^{35} \mathrm{Cl} \mathrm{M}+\mathrm{H}\right]\right]^{+}\right), 270\left(\left[{ }^{37} \mathrm{Cl} \mathrm{M+H}\right]^{+}\right), 290$ $\left(\left[{ }^{35} \mathrm{Cl} \mathrm{M}+\mathrm{Na}\right]^{+}\right)$, and $292\left(\left[{ }^{37} \mathrm{Cl} \mathrm{M}+\mathrm{Na}\right]^{+}\right)$.

$\mathbf{N}$-(2-((5,8-Dioxo-5,8-dihydroquinolin-6-yl)thio)ethyl)acetamide (3j): Orange oil, (0.049 g, 42\% yield). ${ }^{1} \mathrm{H}$ NMR $\left(400 \mathrm{MHz}, \mathrm{DMSO}-d_{6}\right) \delta 9.15-9.08(\mathrm{~m}, 1 \mathrm{H}), 8.42$ (ddd, $\left.J=7.9,1.7,1.2 \mathrm{~Hz}, 1 \mathrm{H}\right), 7.98-7.89(\mathrm{~m}, 2 \mathrm{H}), 3.33-3.24$ $(\mathrm{m}, 2 \mathrm{H}), 3.24-3.15(\mathrm{~m}, 3 \mathrm{H}), 1.69(\mathrm{t}, J=1.4 \mathrm{~Hz}, 3 \mathrm{H}) . \mathrm{MS}(\mathrm{ESI}): \mathrm{m} / z 276$, found $277\left(\mathrm{C}_{13} \mathrm{H}_{12} \mathrm{~N}_{2} \mathrm{O}_{3} \mathrm{~S}[\mathrm{M}+\mathrm{H}]^{+}\right)$.

6,7-Di(pyrrolidin-1-yl)quinoline-5,8-dione (3k): Red dry film, (0.017 g, 25\% yield). ${ }^{1} \mathrm{H} \mathrm{NMR}$ (400 MHz, DMSOd6) $\delta 8.93(\mathrm{dd}, J=4.7,1.7 \mathrm{~Hz}, 1 \mathrm{H}), 8.31$ (dd, $J=7.8,1.7 \mathrm{~Hz}, 1 \mathrm{H}), 7.72(\mathrm{dd}, J=7.9,4.7 \mathrm{~Hz}, 1 \mathrm{H}), 2.03-1.95(\mathrm{~m}$, $8 \mathrm{H}), 1.95-1.90(\mathrm{~m}, 8 \mathrm{H})$. MS (ESI): $\mathrm{m} / z$ 276, found $277\left(\mathrm{C}_{13} \mathrm{H}_{12} \mathrm{~N}_{2} \mathrm{O}_{3} \mathrm{~S}[\mathrm{M}+\mathrm{H}]^{+}\right)$. MS (ESI): $\mathrm{m} / z$ 297, found 298 $\left(\mathrm{C}_{17} \mathrm{H}_{19} \mathrm{~N}_{3} \mathrm{O}_{2}[\mathrm{M}+\mathrm{H}]^{+}\right)$.

6-(Piperidin-1-yl)quinoline-5,8-dione (3I): Red dry film, (0.030 g, 40\% yield). ${ }^{1} \mathrm{H}$ NMR (400 MHz, DMSO- $\left.d_{6}\right) \delta$ $8.93(\mathrm{dd}, J=4.7,1.7 \mathrm{~Hz}, 1 \mathrm{H}), 8.28(\mathrm{dd}, J=7.8,1.7 \mathrm{~Hz}, 1 \mathrm{H}), 7.73(\mathrm{dd}, J=7.9,4.7 \mathrm{~Hz}, 1 \mathrm{H}), 6.10(\mathrm{~s}, 1 \mathrm{H}), 3.50(\mathrm{~s}$, $4 \mathrm{H}), 1.64(\mathrm{~s}, 6 \mathrm{H})$. MS (ESI): $\mathrm{m} / z 242$, found $243\left(\mathrm{C}_{14} \mathrm{H}_{14} \mathrm{~N}_{2} \mathrm{O}_{2}[\mathrm{M}+\mathrm{H}]^{+}\right)$and $265\left([\mathrm{M}+\mathrm{Na}]^{+}\right)$.

6-((3-Methoxyphenyl)amino)quinoline-5,8-dione (3m): Orange dry film, $\left(0.061 \mathrm{~g}, 72 \%\right.$ yield). ${ }^{1} \mathrm{H}$ NMR (400 $\left.\mathrm{MHz}, \mathrm{DMSO}-d_{6}\right) \delta 9.05$ (s, 1H), 8.87 (dd, $J=4.5,1.6 \mathrm{~Hz}, 1 \mathrm{H}$ ), 8.25 (dd, $J=7.8,1.7 \mathrm{~Hz}, 1 \mathrm{H}$ ), 7.79 (dd, $J=7.8,4.7$ $\mathrm{Hz}, 1 \mathrm{H}), 6.73(\mathrm{t}, J=8.1 \mathrm{~Hz}, 1 \mathrm{H}), 6.55(\mathrm{~d}, J=8.0 \mathrm{~Hz}, 1 \mathrm{H}), 6.37(\mathrm{~s}, 1 \mathrm{H}), 6.13(\mathrm{dd}, J=8.1,2.3 \mathrm{~Hz}, 1 \mathrm{H}), 3.40(\mathrm{~s}, 3 \mathrm{H})$. MS (ESI): $m / z 280$, found $281\left(\mathrm{C}_{16} \mathrm{H}_{12} \mathrm{~N}_{2} \mathrm{O}_{3}[\mathrm{M}+\mathrm{H}]^{+}\right)$.

\section{Acknowledgements}

The authors would like to thank the Department of Chemistry and Physics at the University of Tennessee at Chattanooga for research stipend for chemicals and allowing the use of their NMR spectrometer and Mass Spectrometer. This study was supported in part by Southern Adventist University Academic Research Committee Research Sustainability Grant (100-20000-65817) and the 2012 Hamilton Company University Grant Program. 


\section{Supplementary Material}

Copies of NMR, and LCMS spectra of new compounds are available in the Supplementary Material file associated with this manuscript.

\section{References}

1. Alcaín, F. and Villalba, J. Expert Opin. Ther. Pat. 2007, 17(6), pp.649-665. https://doi.org/10.1517/13543776.17.6.649

2. Behforouz, M.; Cai, W.; Mohammadi, F.; Stocksdale, M.; Gu, Z.; Ahmadian, M.; Baty, D.; Etling, M.; Al-Anzi, C. and Swiftney, T. Bioorg. Med. Chem. 2007, 15(1), pp.495-510.

https://doi.org/10.1016/j.bmc.2006.09.039

Bolognese, A.; Correale, G.; Manfra, M.; Esposito, A.; Novellino, E. and Lavecchia, A. J. Med Chem. 2008, 51(24), pp.8148-8157. https://doi.org/10.1021/jm8007689

3. Keyari, C.; Kearns, A.; Duncan, N.; Eickholt, E.; Abbott, G.; Beall, H. and Diaz, P. J. Med Chem. 2013, 56(10), pp.3806-3819. https://doi.org/10.1021/jm301689x

4. Besset, T.; Braud, E.; Jarray, R.; Garbay, C.; Kolb, S.; Leo, P. and Morin, C. Eur. J. Chem. 2011, 2(4), pp.433440.

https://doi.org/10.5155/eurjchem.2.4.433-440.400

5. Balitz, D. M.; Bush, J. A.; Bradner, W. T.; Doyle, T. W.; O’Herron, F. A.; Nettleton, D. E. J. Antibiot. 1982, 35(3), pp.259-265.

https://doi.org/10.7164/antibiotics.35.259

6. Sieveking, I.; Thomas, P.; Estévez, J.; Quiñones, N.; Cuéllar, M.; Villena, J.; Espinosa-Bustos, C.; Fierro, A.; Tapia, R.; Maya, J.; López-Muñoz, R.; Cassels, B.; Estévez, R. and Salas, C. Bioorg. Med. Chem. 2014, 22(17), pp.4609-4620.

https://doi.org/10.1016/j.bmc.2014.07.030

7. Appleton, D.; Pearce, A. and Copp, B. Tetrahedron 2010, 66(27-28), pp.4977-4986. https://doi.org/10.1016/i.tet.2010.05.033

8. Chia, E.; Pearce, A.; Berridge, M.; Larsen, L.; Perry, N.; Sansom, C.; Godfrey, C.; Hanton, L.; Lu, G.; Walton, M.; Denny, W.; Webb, V.; Copp, B. and Harper, J. Bioorg. Med. Chem. 2008, 16(21), pp.9432-9442. https://doi.org/10.1016/j.bmc.2008.09.052

9. Temple, C.; Rose, J. and Montgomery, J. J. Med. Chem. 1974, 17(6), pp.615-619. https://doi.org/10.1021/jm00252a009

10. Ryu, C. K. and Huh, S. H. WO Patent W001/12605A1/PC/KR00/00426, 2001.

11. Fryatt, T.; Goroski, D.; Nilson, Z.; Moody, C. and Beall, H. Bioorg. Med. Chem. Lett. 1999, 9(15), pp.21952198.

https://doi.org/10.1016/S0960-894X(99)00369-8

12. Mulchin, B.; Newton, C.; Baty, J.; Grasso, C.; Martin, W.; Walton, M.; Dangerfield, E.; Plunkett, C.; Berridge, M.; Harper, J.; Timmer, M. and Stocker, B. Bioorg. Med. Chem. 2010, 18(9), pp.3238-3251. https://doi.org/10.1016/j.bmc.2010.03.021 
13. Morin, C.; Besset, T.; Moutet, J.; Fayolle, M.; Brückner, M.; Limosin, D.; Becker, K. and Davioud-Charvet, E. Org. Biomol. Chem. 2008, 6(15), p.2731.

https://doi.org/10.1039/b802649c

This paper is an open access article distributed under the terms of the Creative Commons Attribution (CC BY) license (http://creativecommons.org/licenses/by/4.0/) 